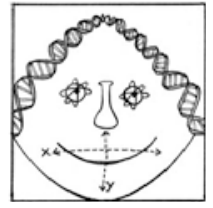

\title{
Science Smiles
}

Ayan Guha

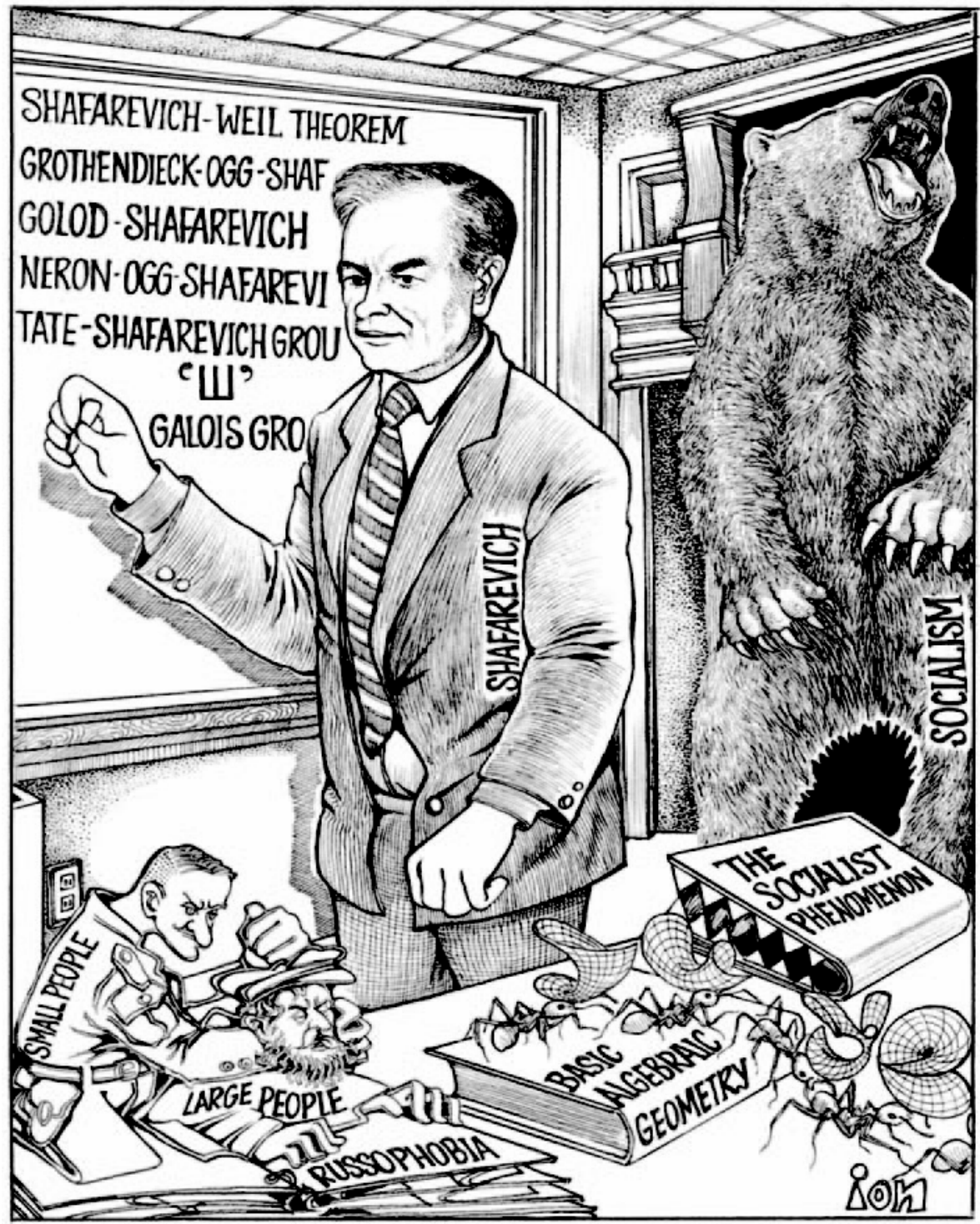

Email for Correspondence: ionguha@gmail.com 